\title{
The implementation of mutual assistance values in a religious day celebration
}

\author{
K. Masita* \& Margono \\ State University of Malang, Malang, Indonesia \\ A.N. Widiadi \\ Victoria University of Wellington, New Zealand
}

\begin{abstract}
Mutual assistance had an important role in the plural society life, there was no exception to the people's life in Balun Village, which was known as a village that had religious and cultural diversity. Thus, mutual assistance played a role as social capital in creating tolerance, maintaining harmony, and preventing conflicts between religious communities. This study aimed to describe the implementation of mutual assistance in religious day celebrations in Balun. This study used a qualitative approach, the data was collected by observation, interview, and document study. The results showed that the implementation of mutual assistance in a religious day celebration was done through community service activities, assisting the preparation of celebrations, donating, and cooperating between religious communities in securing during celebrations. The obstacle faced was the community's activities, therefore not all residents could participate in the implementation of mutual assistance. The efforts made were determining the effective time and giving an announcement or socialization related to the activities to be carried out.
\end{abstract}

Keywords: values, mutual assistance, celebration, religious people

\section{INTRODUCTION}

Indonesia is an archipelago state that consists of various kinds of ethnic groups, this condition makes Indonesia a pluralistic country. It can be seen as sociocultural and geographic which are so complex, diverse, and extensive with various ethnicities, cultures, customs, languages, religions, and so forth. A plural society according to J. S Furnivall by Rustanto (2016) is a society condition that consists of two or more elements, it could be religion, culture, and ideas that live independently without mixing each other but it is coexistence in a political situation. Talking about pluralistic as the official national motto of Indonesia "Bhinneka Tunggal Ika" in the 1945 Constitution of the Republic of Indonesia Chapter XV Article 36 A that has a meaning "Unity in Diversity," the motto does not only function as a byword but also symbolizes the diversity of Indonesia society, which is united in one unit as the Unitary State of the Republic of Indonesia.

The various conditions of society in a multi-cultural context, on the one side it reflects a large national identity, on the other hand, they also have the potential to cause conflicts that threaten national integration. It can be seen on the characteristics of a plural society according to Pierre L Van De Bergh (in Rustanto, 2016) the division of society into groups that have different sub-culture from one another, has a social structure that is divided into institutions that have non-complementary characteristics, difficult to determine an agreement or consensus among its member towards the

${ }^{*}$ Corresponding Author 
basic values, besides, they also experience conflicts relatively frequent between one group and another, their relative social integration grows on coercion and interdependence in the economy sector, and the existence of political domination by one group over the others.

The plurality of society and the potential of the truth can be seen in the people's life in Balun Village, precisely in Turi District, Lamongan. The Balun society life, which has the requirements for diversity, has made the village known as "Pancasila Village" as the village has religious and cultural diversity. There are three major religions in Balun, i.e., Islam, Christianity, and Hinduism which can coexist peacefully until now. The diversity of religious communities in Balun Village is not the reason for conflicts that generally occur in plural societies. However, it becomes a strength for the Balun Village society in showing the unity and integrity attitude. The harmony exists in the Balun Village society just because of the awareness of mutual respect and mutual assistance between religious communities' life. Mutual assistance is a noble value that is believed that have existed in Indonesian life and it can maintain the integrity and unity of society by helping each other and together in the Indonesian diverse life. As explained by Widiyanti and Sunindhia (2003) mutual assistance is a value system of social life that is from generation to generation in the villages life in Indonesia in the form of concrete social attitude. The advantage of this cooperation is to lighten and strengthen relations between residents and unite the Indonesian people or society.

Mutual assistance value has been a vision of Balun Village society to achieve social welfare, through mutual assistance, the community hopes that the desired goal, namely harmony, and prosperity, can be easily achieved. Thus, mutual assistance in that village is very important and worthy to be kept and preserved. To preserve it, they often did mutual assistance or helping each other that was done during the religious celebration among religious communities. The implementation of each religious celebration cannot be separated from helping and cooperating activities that were carried out by society between the same and different religions who also assisted, helped, and worked together in the process of preparation and execution. Therefore, it is expected that Balun Village could be a pluralistic representation, as an inclusive village that provides a space for the society to implement their belief and culture freely with full tolerance, and could be an example in wider for a pluralistic Indonesian society. Based on the introduction that was explained above, it became a special attraction to have a look deeply at the religious communities' life in the village. Then the research title was formulated as "The Implementation of Mutual Assistance Values in Religious Day Celebration in Balun, Turi, Lamongan”.

\section{METHODS}

The study about the implementation of mutual assistance values in religious day celebration in Balun Village used case study research by describing and explaining the various aspects related to an individual, group or organization comprehensively. This research method aimed to maintain the integrity of the object under study by focusing on a case intensively and detail in general (Ulfatin, 2017). The approach used was qualitative by describing a phenomenon about what research subjects have experienced such as behavior, perception, motivation, and action holistically in the form of words and language at the special natural context and by utilizing various natural methods (Moleong, 2007).

The process of collecting data in this study used observation, interviews, and document study techniques. The data sources that were used consisted of two types, namely primary and secondary data. The primary data in this study consisted of: (1) informants involving Balun Village apparatus, community leaders from each religion in Balun Village and the youths or residents of each religion; (2) events, that was religious holidays celebration; and (3) Documents, those were in the form of village profiles. Whereas the secondary data that was used was from the relevant previous studies or events. In this study, the obtained qualitative data that was conducted from July to September 2020 was analyzed through some steps: (1) processing and preparing data; (2) read the whole data; (3) coding the data; (4) applying a coding process to describe settings, categories and themes; and (5) linking the themes/descriptions (Creswell, 2012). 


\section{RESULTS AND DISCUSSION}

\subsection{General description of Balun Village}

"Balun" is the name of a village which was taken from the name of village elder named Mbah Alun which came from the name Sunan Tawang Alun became Mbah Alun then became Mbalun and finally became Balun. Balun Village is a village located in Turi District, Lamongan Regency, East Java with an area of 621.103 hectares. Balun Village is located in the north of Lamongan Regency, about 5 meters from Lamongan District Government center or city center with a distance of \pm 15 minutes. Balun Village consists of 2 (two) hamlets, namely Balun and Ngangkrik with a total population of 4.744 people. Most of the areas in Balun Village are rice fields with an area of approximately 530 hectares. It shows that the agricultural sector has an important role in the economic society. So that the majority of people in Balun Village work as farmers. The heterogeneous and pluralistic conditions community make Balun Village as a special village with a harmony that exists among religious communities, namely Islam, Hinduism, and Christianity as well as the culture that develops in the local community life making Balun Village known as "Pancasila Village."

\subsection{The implementation of mutual assistance in religious day celebration in Balun}

The development of various beliefs or religions in Balun Village is not only a set of thoughts that regulate the relationship between humans and God but also the relationship between humans and other humans, and between humans and their natural environment. According to Lubis (2015) the role of religion based on its function consist of two, there are: (1) functions to provide the understanding and explain the viewpoint regarding the world that cannot be reached by humans (beyond), which can lead to significant depression and frustration. Besides, religion also teaches about the awareness of the world view which will come out a work ethic as an ideal reward that a person will receive afterlife (eschatological); (2) religion functions as a ritual that allows human relations with things out of range.

Based on the results of this study, it was known that each religion in Balun Village has different religious activities with various kinds of celebrations. Other religious feast days except during feast celebration tend to be carried out simply and internally, whereas the annual year celebration on a bigger scale is only carried out during the feast. Therefore, in the discussion about the feast day of each religion i.e., Eid al-Fitr as a holiday celebration for Muslims, Nyepi as a holiday celebration for Hindus, and Christmas reception as a holiday celebration for Christians.

Based on each of the implementation of religious holidays, it could be seen that in the celebration of religious holidays in Balun Village, it was found that there were various kinds of implementation of the mutual assistance values. According to the Ministry of Education and Culture (1982) mutual assistance is cooperation in achieving certain goals with the reciprocity principle which creates social activities in society life. Mutual assistance can vary according to the field and social activity. For the implementation, mutual assistance can be spontaneous, it based on a purpose or because they want to fulfill a social obligation for community activities. The various mutual assistance activities in the religious holiday celebration could be grouped by types. According to Bintarto (1980) explained that the forms of mutual assistance are: (1) A mutual assistance in collecting donation of the energy for the common interest; (2) A mutual assistance in collecting donation of thoughts for the common interest; (3) A mutual assistance in collecting donation of funds for the common interest.

The implementation of mutual assistance value in collecting energy in the religious holiday's celebration in Balun Village, it could be seen in the community service activities that carried out during the celebration of Eid al-Fitr, Nyepi, and Christmas. As explained by Nafisah and Sarmini (2020) in their study that mutual assistance in cleaning the village has become a culture for the society which is carried out in the community service activities. Besides commemorating Independence Day, community service activities are also often carried out on big holidays such as 
before the feast which is carried out by cleaning the tombs. Thus, community service has become a mutual assistance tradition for society.

In addition, the community service in the form of manpower assistance is also carried out by Balun Village society by helping the process of safeguarding and orderliness of the implementation of the feast in each religion. The assistance is not only carried out by the fellow religious members but also with people of different religions assistance and cooperation. It is in line with the study conducted by Rahmayanti (2017) explained that the religious days celebration of all religions; Islam, Hindu, and Cristian take turns in maintaining security and order during religious celebrations. Therefore, between Muslims and Hindus or Cristian and vice versa, they work together, assisted by the authorities to maintain environmental security.

According to Sastropoetro participation was done in reaching the goals by showing the involvement either spontaneously or accompanied by awareness and responsibility for the interest of the group (in Isbandi, 2007). Several forms of community participation are participation in the form of force, participation in the form of funds, participation in the form of material, and participation in the form of information. While the implementation of mutual assistance values in the form of collecting funds voluntarily was seen in the celebration of Eid al-Fitr, it was shown by the participation of the society in Balun Village who made contributions or gave donations voluntary which were used to fulfill all the needs of the celebration. This is in line with the study of Wadu et al. (2019) stated that activities to help each other in community life that aim to advance welfare is also done by giving donations either giving money or things without expecting anything in return or voluntarily. So, it is not only giving force and funds, mutual assistance value in feast celebration can also be implemented in participating in thought which is manifested in the activity of making ogoh-ogoh statues in Nyepi celebration in Balun Village, not only Hindus are involved but also other religions people help it.

\subsection{The obstacle faced and the efforts made to overcome in implementing mutual assistance value in the religious day in Balun}

The obstacle faced in implementing mutual assistance value in the religious day in Balun Village was the community's activities, it showed that not all citizens could follow or help the implementation of mutual assistance. The constraint was caused since some people still worked and some of them still conduct their study for the youth who usually helped and participated in implementing mutual assistance for religious holidays celebration. According to Rismayanto (2016) the study explained that the shift of mutual assistance value is due to the business that makes people slowly start to leave the mutual assistance culture. The reason became commonplace among residents because of the lack of free time to participate in mutual assistance activities. The shift has been going on for a long time and the changes are gradually being felt until now. It is in line with the study that was conducted by Febriani (2019) the shift of mutual assistance value is caused by the level of community activity, where the community has a heterogeneous activity which causes many people to feel tired and prefer to take a rest rather than taking a part in community service.

The efforts made to overcome the obstacles faced in implementing mutual assistance values in the religious day in Balun Village were conducted by the following two attempts: (1) determining the effective time by considering the effectiveness in determining the schedule for the implementation of activities related to the mutual assistance in celebrating religious holidays; (2) giving an announcement or socialization related to the activities to be carried out, it is in line with the research result by Nilnawati and Haris (2017) that the efforts made in maintaining the mutual assistance value by providing appeals and motivating the society to maintain and preserve the mutual assistance culture is a hereditary culture and it has existed for a long time, therefore it deserves to be upheld. Besides making an event schedule, announcement or socialization is needed as an effort to make the society aware of the agenda to be carried out. It is hoped that the announcement announces in advance make the increasing of society awareness to spend their time and participate in mutual assistance activities on religious holidays. These findings can be juxtaposed with Vander's opinion 
(1979) socialization is an interactive social process that affects an individual's how to think, feel, and behave so that they can participate in community life.

\section{CONCLUSIONS}

The mutual assistance values in religious holidays celebration in Balun Village was manifested by the existence of various activities in helping or cooperating which was carried out by the society through (1) community service; (2) donating; (3) helping the security of celebration; to (4) creating ogoh-ogoh statue. The process of implementing mutual assistance values still had obstacles that were faced, it was the community's activities, so not all residents could participate or help the implementation of mutual assistance. It was because when the activity took place, some residents were at work, school, and college, and also the schedule coincided with other activities. The efforts made to overcome these obstacles were by determining the effective time for the implementation of activities related to mutual assistance and providing announcements or socialization related to the activities to be carried out. Those efforts were expected could make the residents prepared themselves and took the time to participate in mutual assistance activities on religious holidays.

\section{REFERENCES}

Department of Education and Culture. 1982. Village community mutual assistance. Jakarta: Ministry of Education and Culture.

Creswell, J. 2012. Research design; Quantitative and mixed qualitative approaches. Yogyakarta: Student Library.

Febriani, et al. 2019. Factors that cause shifting values of mutual cooperation: The level of community activity and the activeness of their leaders. Scientific Journal of Student Reasoning and Research 3(2): 41-50.

Isbandi, R.A. 2007. Participatory planning based on community assets. Depok: FISIP IU Press.

Lubis, R. 2015. Sociology of religion: Understanding the development of religion in social interaction. Jakarta: Prenadamedia Group.

Moleong, L.J. 2007. Qualitative research methods. Bandung: PT Remaja Rosdakarya.

Nilnawati, R. \& Haris, H. 2017. The shifting value of mutual cooperation in Tamasaju village, Galesong Utara District, Takalar Regency. Tomalebbi: Journal of Thought, Legal Research, Pancasila Education and Citizenship 4(4):172-187.

Nafisah. A \& Sarmini. 2020. Cultural transformation of mutual cooperation in the era of globalization in the Bawean island community. Moral and Citizenship Studies 8(2): 383-400.

Rahmayanti. L. \& Yani, M.T. 2017. Practices of religious pluralism in Balun village, Turi district, Lamongan regency. Moral and Citizenship Studies 5(1): 16-30.

Rismayanto, I. 2016. The shifting of mutual cooperation values in the community of Gegerkalong village, Sukasari district, Bandung regency. Retrieved from: http://repository.upi.edu.

Rustanto, B. 2016. Indonesian multicultural society. Bandung: PT. Rosdakarya youth.

Ulfatin, N. 2017. Qualitative research methods in the field of education: Theory and its applications. Malang: Media Nusa Creative.

Wadu L.B. et al. 2019. Mutual fundraising in Manggarai culture. Prosiding: National Seminar on Education and Learning for Teachers and Lecturers 3: 83-89.

Widiyanti \& Sumindhia. 2003. Indonesian Cooperatives and Cooperatives. Jakarta: PT. Rineka Cipta.

Vander, Z.J.W. 1979. Sociology. New York: Jhon Wiley and Sons. 